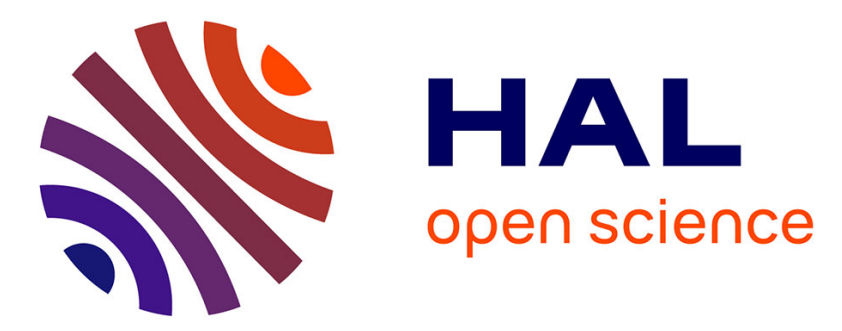

\title{
Spatial Ecotoxicology: Migratory Arctic Seabirds Are Exposed to Mercury Contamination While Overwintering in the Northwest Atlantic
}

Jérôme Fort, Gregory J Robertson, David Grémillet, Gwendoline Traisnel, Paco Bustamante

\section{To cite this version:}

Jérôme Fort, Gregory J Robertson, David Grémillet, Gwendoline Traisnel, Paco Bustamante. Spatial Ecotoxicology: Migratory Arctic Seabirds Are Exposed to Mercury Contamination While Overwintering in the Northwest Atlantic. Environmental Science and Technology, 2014, 48, pp.11560 - 11567. 10.1021/es504045g . hal-01100234

\author{
HAL Id: hal-01100234 \\ https://hal.science/hal-01100234
}

Submitted on 18 Mar 2015

HAL is a multi-disciplinary open access archive for the deposit and dissemination of scientific research documents, whether they are published or not. The documents may come from teaching and research institutions in France or abroad, or from public or private research centers.
L'archive ouverte pluridisciplinaire HAL, est destinée au dépôt et à la diffusion de documents scientifiques de niveau recherche, publiés ou non, émanant des établissements d'enseignement et de recherche français ou étrangers, des laboratoires publics ou privés. 


\section{Spatial ecotoxicology: migratory Arctic seabirds are exposed to mercury contamination while overwintering in the Northwest Atlantic}

Jérôme Fort ${ }^{*}, 1$, Gregory J. Robertson ${ }^{2}$, David Grémillet ${ }^{3,4}$, Gwendoline Traisnel ${ }^{1}$, Paco Bustamante $^{1}$

${ }^{1}$ Littoral Environnement et Sociétés, UMR 7266 CNRS-Université La Rochelle, 2 rue Olympe de Gouges, 17000 La Rochelle, France

${ }^{2}$ Wildlife Research Division, Environment Canada, 6 Bruce Street, Mount Pearl, NL, Canada

${ }^{3}$ Centre d'Ecologie Fonctionnelle et Evolutive, UMR 5175 du CNRS, 1919 route de Mende, 34293 Montpellier, France

${ }^{4}$ Percy FitzPatrick Institute, DST/NRF Centre of Excellence, University of Cape Town, Rondebosch 7701, South Africa

*Corresponding author. Email: fort.jerome@gmail.com; Tel: +33 546458388 


\begin{abstract}
Arctic organisms are exposed to various levels of pollutants, among which mercury $(\mathrm{Hg})$ has raised important environmental concerns. Previous studies examining $\mathrm{Hg}$ levels, trends and effects on Arctic marine top-predators have focused on the Arctic region. However, many of these top-predators, such as seabirds, migrate to spend a large part of their life-cycle far from the Arctic in areas where their exposure to contaminants is largely unknown. By combining biotelemetry, $\mathrm{Hg}$ and stable isotope analyses, we studied the seasonal $\mathrm{Hg}$ contamination of little auks (Alle alle; the most abundant Arctic seabird) in relation to their distribution and marine foraging habitat, as well as its potential impacts on bird reproduction. We show that little auks were about 3.5 times more contaminated when outside the breeding season, and that $\mathrm{Hg}$ accumulated during this non-breeding non-Arctic period was related to egg size the following season with females having more $\mathrm{Hg}$ laying smaller eggs. Our results highlight that ecotoxicological studies should be expanded to yield a comprehensive understanding of contamination risks and associated threats to top-predators over their entire annual cycle. Furthermore, we show that an important non-breeding area located in the northwest Atlantic was associated with higher $\mathrm{Hg}$ contamination and demonstrate the utility of bird-borne miniaturized technology to evaluate the contamination of marine systems at large spatial scales.
\end{abstract}


TOC/Abstract Art.
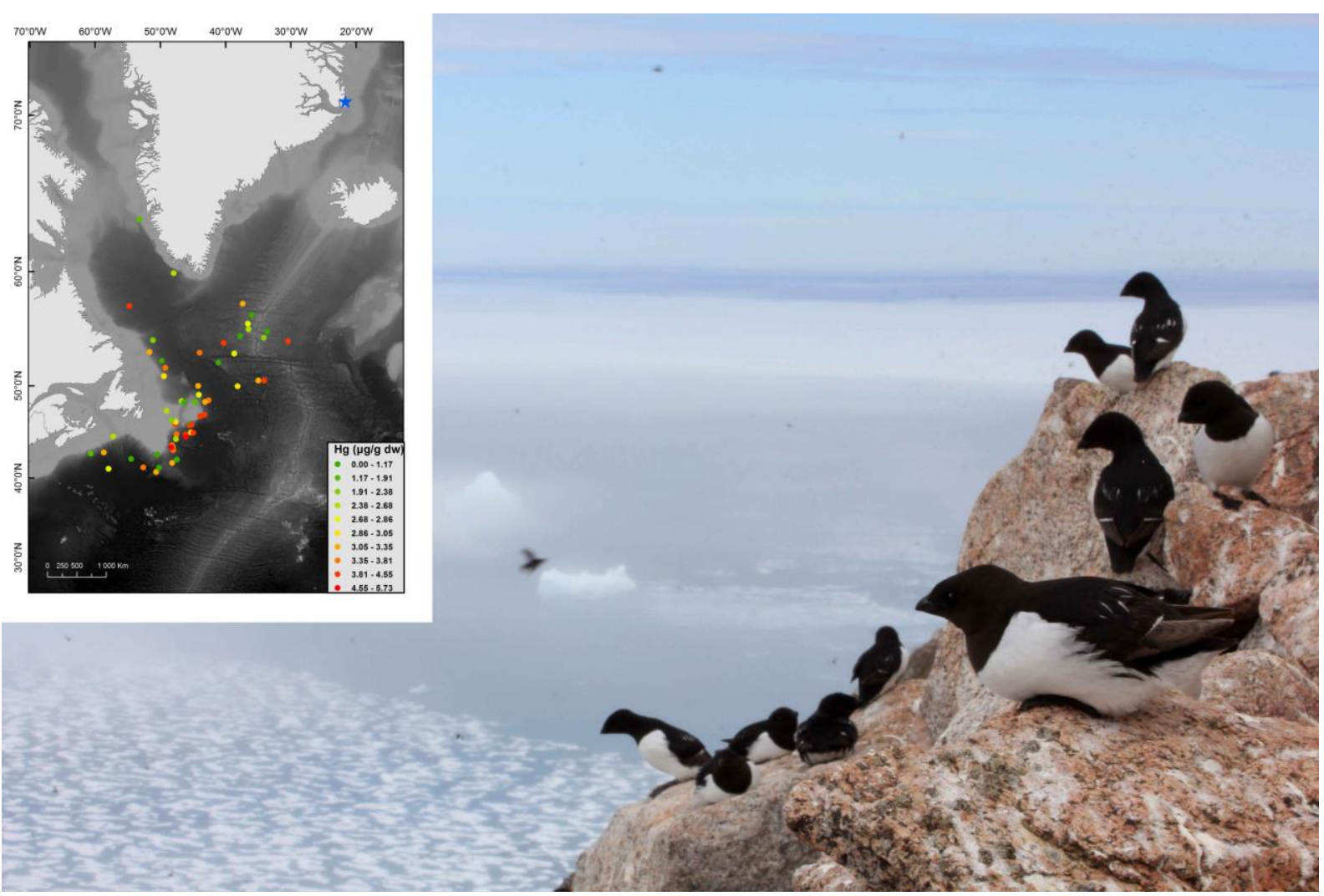


\section{Introduction}

Although lying far from major human industries, the Arctic region is threatened by pollution risks and pollutant levels. Transported over large distances by ocean currents and atmospheric circulation, many pollutants originating from industrialized or developing countries are deposited into the Arctic. ${ }^{1,2}$ More recently, sea-ice cover is much reduced in some areas, releasing pollutants trapped over decades and opening up new areas to human activities such as shipping and extractive industries, thereby increasing direct discharges of pollutants into Arctic ecosystems. ${ }^{3,4}$ As a consequence of all these activities, concentrations of pollutants such as trace metals or hydrocarbons have increased in some parts of the Arctic over the last decades. ${ }^{5-7}$ Once in the environment, pollutants can become bioavailable, enter the food-chain and can have major impacts on organisms and biodiversity. Among pollutants that are liable to affect Arctic wildlife, mercury $(\mathrm{Hg})$ has raised important environmental concerns and drawn extensive attention. ${ }^{8}$ This non-essential metal is highly toxic, particularly in its main organic form of methylmercury, and even at low concentrations has been shown to be a powerful neurotoxin. ${ }^{9,10}$ In this context, defining concentrations, trends and ecotoxicological effects of $\mathrm{Hg}$ on Arctic organisms is important in order to develop strategies for conservation of vulnerable species and ecosystems. Recently, the Arctic Monitoring and Assessment Programme (AMAP) working group of the Arctic Council published an extensive review of the current knowledge about the Hg-contamination of Arctic species and the deleterious effects of $\mathrm{Hg}^{8}{ }^{8}$ This group emphasized the importance of focusing on marine top predators since they are expected to be exposed to high concentrations of $\mathrm{Hg}$ through bioaccumulation and biomagnification. ${ }^{11}$

Marine top-predators, such as seabirds, can be highly mobile during their annual cycle. For instance, many seabird species leave the Arctic after their breeding season and migrate 
hundreds to thousands kilometres to winter areas, spending many months of the year outside of the Arctic, in boreal, temperate or even tropical regions. ${ }^{12-14}$ There, they could face environments equally or even more contaminated than the Arctic ${ }^{15}$ and therefore accumulate high concentrations of $\mathrm{Hg}$ which could in turn have impacts on their physiology and behaviour and ultimately reproduction, survival and populations dynamics. ${ }^{16,17}$ Understanding exposure to pollutants, including $\mathrm{Hg}$, during the season spent outside the Arctic is therefore essential to obtain a complete view of the risk faced by these organisms in a changing environment. Nevertheless, and to our knowledge, only one recent study, focused on persistent organic pollutants (POP), previously linked Arctic seabird contamination to their non-Arctic winter areas, highlighting the importance of considering the entire annual cycle in ecotoxicology studies. ${ }^{18}$ This focus on the annual cycle has yet to be considered for $\mathrm{Hg}$ in the Arctic seabirds. In this study, we examined and compared $\mathrm{Hg}$ concentrations measured in little auks (Alle alle), a small Arctic seabird, during different periods of the year and in relation to their winter distribution. We also investigated how $\mathrm{Hg}$ accumulated during the non-breeding period could affect their reproduction.

The little auk represents an ideal species to investigate $\mathrm{Hg}$ contamination of Arctic seabirds during the breeding and non-breeding periods. This species, like most of the alcids, moults twice per year; a complete feather moult soon after the breeding season (September) involves the replacement of the entire body plumage while a partial pre-breeding moult occurring during spring involves the replacement of throat and head feathers. ${ }^{19-21}$ The timing of this prebreeding moult is not accurately known. However, little auks collected in March at their wintering site were all in winter plumage ${ }^{22}$ while birds seen at breeding colonies in May are in breeding plumage. It is therefore likely that little auks moult their head and throat feathers in April, before arriving at their colony. The feather moult, along with egg production, is a mechanism by which seabirds excrete $\mathrm{Hg}$ accumulated in their body tissues, ${ }^{23}$ which makes 
concentrations measured in feathers an indicator of $\mathrm{Hg}$ levels accumulated since the last moulting sequence. ${ }^{24-26}$ Hence, it can be assumed that $\mathrm{Hg}$ concentrations measured in little auk head feathers reflect contamination accumulated during the non-breeding period while cover feathers from other parts of the body reflect contamination accumulated during the breeding season.

By analysing $\mathrm{Hg}$ concentrations in blood and feathers and combining these results with data on bird movement and wintering areas, obtained with biotelemetry tracking and stable isotope analysis, we tested the following hypotheses: (1) little auk $\mathrm{Hg}$ contamination is higher during the non-breeding season spent outside of the Arctic. (2) Contamination of birds is related to their non-breeding distribution and foraging habitat. (3) $\mathrm{Hg}$ levels accumulated during the non-Arctic non-breeding period affect the reproduction of little auks.

\section{Materials and Methods}

Study sites and sample collection

In July 2009 and 2010, a total of 135 adult little auks breeding at Kap Höegh (East Greenland; $\left.70^{\circ} 44^{\prime} \mathrm{N}, 21^{\circ} 35^{\prime} \mathrm{W}\right)$ were equipped with a miniature geolocator data-logger (GLS; Mk14 and Mk18L, British Antarctic Survey, mass $=1.5 \mathrm{~g}, \sim 1 \%$ of adult body mass) mounted on a conventional metal leg ring in order to track their non-breeding movements and distribution. $^{27,28}$ The following years, birds were recaptured (2010: $\mathrm{n}=47$ (22 males, 24 females and one unknown sex), 2011: $n=35$ (22 males and 13 females)), the data logger retrieved and downloaded, and blood and feather samples collected. Blood samples $(\sim 0.3 \mathrm{ml})$ were collected from the brachial vein, stored in seventy percent ethanol, and kept frozen at $20^{\circ} \mathrm{C}$. Two batches of feathers were plucked from each bird: 1 from the body (back or belly) 
and 1 from the head (cheek, neck or throat). These 2 batches are hereafter called 'body feathers' and 'head feathers', respectively. All feathers were kept at ambient temperature in sealed plastic bags until analysis. A few additional feathers were collected and stored at $-20^{\circ} \mathrm{C}$ for subsequent molecular sexing.

Little auks nest in crevices in talus slopes and lay one single egg per breeding season. When accessible, eggs of tracked birds were measured (maximal length $(L)$ and breadth $(B)$ ) and their volume $(V)$ calculated following the equation $V=\pi / 6 \times L B^{2} / 1000 .{ }^{29}$ Nests were then checked every two days until hatching to determine for each nest the hatching date. Evidence of hatching was provided by the direct sight of a chick or by the presence of egg shell fragments in the nest chamber.

Little auks were also collected in Placentia Bay (Newfoundland; 47 $30^{\prime} \mathrm{N}, 54^{\circ} 00^{\prime} \mathrm{W}$ ) in March 2011 and immediately kept frozen at $-20^{\circ} \mathrm{C}$ until dissections. ${ }^{22}$ Newfoundland waters are known to be the main wintering quarter for little auks breeding in Greenland, including those from East Greenland. ${ }^{27,28}$ From these carcasses, blood samples were collected (from the cardiac clot) and kept frozen at $-20^{\circ} \mathrm{C}$ until analysis.

$\mathrm{Hg}$ and stable isotope analyses

Prior to analyses, feathers were cleaned in order to remove any external contamination. Feathers were rinsed once in a 2:1 chloroform:methanol solution and twice in a methanol solution. Feathers were then dried for $48 \mathrm{~h}$ at $50^{\circ} \mathrm{C}$. Blood samples were dried for $72 \mathrm{~h}$ at ambient temperature to remove ethanol and then lyophilized for $48 \mathrm{~h}$.

Total $\mathrm{Hg}$ (hereafter referred to as $\mathrm{Hg}$ ) concentrations were measured in whole blood and feather samples collected from little auks breeding at Kap Hoëgh and in blood samples 
collected from little auks wintering off Newfoundland. $\mathrm{Hg}$ analyses were performed at the Littoral Environnement et Sociétés laboratory (LIENSs, La Rochelle, France) on ca. $3 \mathrm{mg}$ of homogenized whole blood or on 1 complete feather, using an advanced $\mathrm{Hg}$ analyzer spectrophotometer (Altec AMA 254). ${ }^{30}$ Analyses were repeated 2-3 times for each sample until the relative standard deviation for two samples was $<10 \%$, samples not meeting this criterion were excluded from the analysis. The mean $\mathrm{T}-\mathrm{Hg}$ concentrations for those two measurements were then considered for statistical analyses. To ensure accuracy of measurements, a certified reference material was used (Lobster Hepatopancreas Tort-2; NRC, Canada; Hg concentration: $0.27 \pm 0.06 \mu \mathrm{g} \cdot \mathrm{g}^{-1}$ dry weight $\left.(\mathrm{dw})\right)$ and measured every 10 samples. Average measured value was $0.26 \pm 0.01 \mu \mathrm{g} \cdot \mathrm{g}^{-1} \mathrm{dw}, \mathrm{n}=44$. Additionally, blanks were run at the beginning of each sample set. The detection limit of the method was 0.005 $\mu \mathrm{g} \cdot \mathrm{g}^{-1} \mathrm{dw}$.

Stable isotope carbon ratios were measured on non-lipid extracted whole blood samples, ${ }^{31}$ collected from little auks wintering off Newfoundland. Analyses were performed at LIENSs on ca. $0.5 \mathrm{mg}$ subsamples of material loaded into tin cups, using an elemental analyser (Thermo Fisher, Flash EA 1112) coupled in continuous flow mode to an isotope ratio mass spectrometer (Thermo Fisher, Delta V Advantage, Bremen, Germany). Stable isotope abundances were expressed in $\delta$ notation as the deviation from standards in parts per thousand (\%o) according to the following equation: $\delta^{13} \mathrm{C}=\left[\left(\mathrm{R}_{\text {sample }} / \mathrm{R}_{\text {standard }}\right)-1\right] \times 1000$, where $\mathrm{R}$ is the molar ratio ${ }^{13} \mathrm{C} /{ }^{12} \mathrm{C}$. Standard values for $\mathrm{C}$ were Vienna-PeeDee Belemnite (VPDB). Replicate measurements of internal laboratory standards (acetanilide) indicated that measurement error was \pm 0.06 .

The $\delta^{13} \mathrm{C}$ isotopic values mainly reflect the carbon source (i.e. foraging habitat) used by birds. $^{32}$ 


\section{Spatial analyses}

Light-level data were extracted from GLS loggers and processed following published procedures. ${ }^{28}$ Briefly, light-level data were converted into positions using the BASTrak software package (BAS, Cambridge, UK). We used threshold light intensity of 10, an angle of sun elevation of $-3.0^{\circ}$, and applied compensation for movements. The angle of sun elevation was defined following the 'Hill-Ekstrom calibration' method. ${ }^{33}$ For each equipped bird, two positions were obtained per day (at local noon and midnight). From individual positions, we then calculated the median geographical position occupied by each tracked bird during the non-breeding period (15 October - 20 February). Since day and night durations are equal during equinoxes, bird non-breeding positions from 20 February to 1 April could not be accurately determined from light-level recordings and were therefore not included in the analysis. Spatial analyses were performed using ArcMap 10.1 (ESRI, Redlands, CA, USA).

\section{Statistical analyses}

Statistics were computed using R software, version 3.0.2 (R Development Core Team 2011). Differences of $\mathrm{Hg}$ concentrations between seasons, sexes and years were tested using Student's t-tests or Mann-Whitney tests in cases where distributions were not close to normal. We used a multiple linear regression to test for a relationship between $\mathrm{Hg}$ concentrations accumulated during the non-breeding period (as reflected by $\mathrm{T}-\mathrm{Hg}$ concentrations in head feathers) and the non-breeding distribution of birds, defined as their median longitude and latitude between 15 October and 20 February. Simple linear regressions were used to investigate whether $\mathrm{Hg}$ concentrations were linearly correlated to $\delta^{13} \mathrm{C}$ values and whether little auk egg volumes and hatching date were correlated to $\mathrm{Hg}$ concentrations measured in 
head feathers. For these two latter relationships, only females were considered. Values are presented as means $\pm \mathrm{SD}$, and statistical significance was assumed at $\mathrm{p}<0.05$.

\section{Results}

$\mathrm{Hg}$ concentrations were slightly but significantly higher in 2011 than in 2010 in blood samples collected during the breeding season (t-test: $\mathrm{t}=3.51$, $\mathrm{df}=61, \mathrm{p}<0.001)$ and in body feather samples (Mann-Whitney test, $\mathrm{U}=245, \mathrm{p}<0.01$ ) (see Supporting Information (SI) Figure S1). Hg concentrations in head feathers were similar in 2011 and in 2010 (t-test: $t=$ $0.41, \mathrm{df}=61, \mathrm{p}=0.68$; see SI Figure S1). No difference was found between male and female Hg concentration in body and head feathers $(t=0.62, d f=63, p=0.54$ and $t=0.20, d f=61, p$ $=0.84$, respectively). However, breeding males had slightly but significantly higher blood $\mathrm{Hg}$ concentrations than females ( $\mathrm{t}$-test: $\mathrm{t}=3.58 \mathrm{df}=61, \mathrm{p}<0.001$; SI Figure S2). Importantly, differences observed between years and sexes did not affect the contrasting seasonal $\mathrm{Hg}$ contamination patterns observed in little auks (see below).

\section{Seasonal Hg contamination}

Hg concentrations measured on blood samples were higher in non-breeding (wintering) than in breeding little auks (Mann-Whitney test, $\mathrm{U}=0, \mathrm{p}<0.001, \mathrm{n}=14$ and 63, respectively; Figure 1). During the non-breeding season off Newfoundland, birds had an average $\mathrm{Hg}$ concentration in blood of $2.86 \mu \mathrm{g} \cdot \mathrm{g}^{-1} \mathrm{dw} \pm 0.78(\min =1.72, \max =4.25)$ while this concentration was $0.84 \mu \mathrm{g} \cdot \mathrm{g}^{-1} \mathrm{dw} \pm 0.20(\min =0.44, \max =1.25)$ for individuals breeding in East Greenland. A similar trend was found in feather samples, $\mathrm{Hg}$ concentrations in head feathers were significantly higher than in body feathers ( $\mathrm{t}$-test: $\mathrm{t}=11.07, \mathrm{df}=126, \mathrm{p}<0.001$; 
Figure 1). Head feather concentrations (average $=3.17 \mu \mathrm{g} \cdot \mathrm{g}^{-1} \mathrm{dw} \pm 0.83, \min =1.53, \max =$ 5.73, $\mathrm{n}=81)$ reflect contamination during the non-breeding period while body feather concentrations (average $=1.53 \mu \mathrm{g} \cdot \mathrm{g}^{-1} \mathrm{dw} \pm 0.84, \min =0.71, \max =4.33, \mathrm{n}=78$ ) reflect contamination during the breeding season (see Introduction for details).

Hg contamination vs non-breeding distribution

$\mathrm{Hg}$ concentrations were negatively and linearly correlated to $\delta^{13} \mathrm{C}$ values in blood samples collected during winter $\left(F_{1,12}=7.92, \mathrm{p}=0.02, R^{2}=0.35\right.$; Figure 2$)$, indicating that nonbreeding $\mathrm{Hg}$ contamination of little auks is linked to their foraging habitat. The multiple regression analysis showed a significant relationship between bird median position during the non-breeding season and $\mathrm{Hg}$ concentrations measured in head feathers $\left(F_{2,46}=3.78, \mathrm{p}=0.03\right.$, $\left.R^{2}=0.10\right)$, with $\mathrm{Hg}$ concentrations were higher in birds wintering at more southerly $(\mathrm{p}=0.02)$ and westerly $(\mathrm{p}=0.03)$ positions. More specifically, little auks with a median non-breeding position located along the eastern slopes of the Grand Banks of Newfoundland and the Flemish Cap were globally more contaminated compared to other areas (Figure 3).

Relationship between female $\mathrm{Hg}$ contamination and their reproduction

A negative linear relationship between $\mathrm{Hg}$ concentrations in female head feathers (i.e. nonbreeding $\mathrm{Hg}$ contamination) and their egg size was observed $\left(R^{2}=0.18, F_{1,16}=4.83, \mathrm{p}=0.04\right.$; Figure 4). There was no relationship between $\mathrm{Hg}$ concentrations in female head feathers and hatch dates $\left(R^{2}=0.0, F_{1,9}=0.007, \mathrm{p}=0.94\right)$. Furthermore, there was no relationship between female blood $\mathrm{Hg}$ concentrations and their body mass at recapture or between female head feather $\mathrm{Hg}$ concentrations and their median non-breeding position (all $\mathrm{p}>0.2$ ). 


\section{Discussion}

$\mathrm{Hg}$ concentrations have previously been measured in a large variety of Arctic seabirds and other top-predators. ${ }^{8,34}$ These studies provided essential information about $\mathrm{Hg}$ concentrations in organisms, ${ }^{34}$ about their trends over past decades or centuries, ${ }^{6}$ as well as about the ecotoxicological effects of this contaminant. ${ }^{10}$ This work has greatly improved our understanding of the threat posed by mercury to the Arctic wildlife, and of the risks associated with increases of $\mathrm{Hg}$ in the marine environment. Nevertheless, all of this work focused on the Arctic region, mainly during summer when seabirds are breeding, which excludes a large part of the annual cycle. Consequently, and to our knowledge, no study previously investigated the intra-individual seasonal $\mathrm{Hg}$ contamination of Arctic seabirds. This is unfortunate since seabirds can travel over large distances and spend the non-breeding period far from their breeding site to non-Arctic areas where their exposure to contaminants remains largely unknown. Taking advantage of the specific moulting pattern of little auks and by combining biotelemetry, $\mathrm{Hg}$ and stable isotope analyses, our results demonstrate that ecotoxicological studies should be extended to yield a comprehensive understanding of contamination risks and associated threats to seabirds and other top-predators over their entire annual cycle. Indeed, we show by analysing blood samples that little auks breeding in East Greenland and wintering in the northwest Atlantic off Newfoundland were 3.5 times more contaminated during the winter period. This difference was lower in feather samples, but contamination over the non-breeding period was still twice as high. $\mathrm{Hg}$ concentrations measured in feathers reflect the amount accumulated in body tissues since the last moult ${ }^{24-26}$, which corresponds to a period extending from approx. April to September for little auk body feathers. ${ }^{20,21}$ Although we considered this period as the breeding season, it also includes a period of post-breeding movements (between the breeding site in East Greenland and a moulting area in the 
Greenland Sea $)^{21,28}$ as well as pre-breeding movements, as it is unlikely that little auks moult their summer plumage at their breeding site. ${ }^{19,28}$ During these short periods, little auks were in areas where their exposure to $\mathrm{Hg}$ was possibly different than at their breeding site, ${ }^{8,35}$ leading to slightly higher $\mathrm{Hg}$ concentrations in body feathers when compared to blood samples.

The AMAP 2011 Impact Assessment reviewed several studies that investigated the nonbreeding distribution and $\mathrm{Hg}$ contamination of various seabird species. ${ }^{36-41}$ From their results, AMAP suggested that the lack of a significant temporal trend in $\mathrm{Hg}$ concentrations of Arctic seabirds that winter at low latitudes, outside of the Arctic, could be explained by a lower exposure to $\mathrm{Hg}$ during their non-breeding period, in contrast to species wintering at higher latitudes which showed increasing $\mathrm{Hg}$ levels. ${ }^{8}$ Here we demonstrate that this explanation should not be generalized to all species wintering in the northwest Atlantic, which may actually be exposed to higher $\mathrm{Hg}$ contamination when not breeding. An alternative hypothesis to explain the lack of trend reported by AMAP is that species and populations considered in their study did not winter in the northwest Atlantic as supposed, but in other regions where $\mathrm{Hg}$ concentrations are lower. Our results indeed confirm that the geographical position as well as the foraging habitat used by birds can affect their $\mathrm{Hg}$ contamination. In the northwest Atlantic, we found that little auk $\mathrm{Hg}$ contamination was higher in birds that had median nonbreeding positions to the south and west. Within the Arctic, Mallory and Braune ${ }^{42}$ also highlighted a relationship between seabird breeding distribution in the Canadian Arctic and their $\mathrm{Hg}$ concentrations, with birds breeding in the High Arctic being more contaminated than those from the low Arctic. ${ }^{42}$ Isotopic results showed that wintering birds with enriched carbon ratios were less contaminated. The $\delta^{13} \mathrm{C}$ ratio is an indicator of the source of primary production in marine systems and can also be used to indicate inshore versus offshore contribution to feeding habitats. ${ }^{43,44}$ Since enriched carbon values in marine predators have been showed to correspond to a more inshore diet, ${ }^{43,44}$ this suggests that little auks foraging 
closer to the shore were less exposed to $\mathrm{Hg}$ contamination than birds that had recently foraged offshore. This difference could either reflect contrasting baseline Hg contamination of these habitats, or be the result of a different diet when foraging offshore and inshore with contrasting contamination levels of consumed prey items. ${ }^{45}$ Our results therefore highlight the need to extend seasonal contamination studies and focus on additional populations and species that spend the non-breeding season in different regions and habitats where $\mathrm{Hg}$ exposure is different. ${ }^{35}$ Studies combining contaminant analyses, biotelemetry and an isotopic approach will provide essential knowledge of the seasonal contamination of Arctic seabirds and confirm the pollution risk that regions south of the Arctic represent for this community (see also ${ }^{18}$ for persistent organic pollutants). For instance, little auks breeding in Spitsbergen winter at higher latitudes than Greenlandic breeders. ${ }^{28}$ Other species, such as kittiwakes (Rissa tridactyla), guillemots (Uria spp.), and razorbill (Alca torda) overwinter in different areas of the North Atlantic, ${ }^{13,46,47}$ whereas long-tailed skua (Stercorarius longicaudus) and Sabine's gulls (Larus sabini) migrate to the South Atlantic Ocean along the West African coasts. ${ }^{14,48}$ Moreover, future studies could also help identify, at large spatial scales, sensitive areas where contamination risks are higher for Arctic wildlife. In this context, our results suggest that long-lived top-predators such as seabirds can be efficient indicators of the state of contamination of entire marine systems, by integrating contaminant concentrations at a large spatial scale and across marine food webs. Accordingly, our results indicate that the area located along the eastern slopes of the Grand Banks of Newfoundland and the Flemish Cap was associated with higher $\mathrm{Hg}$ contaminations and merits further attention.

As mentioned above, $\mathrm{Hg}$ contamination of organisms is also closely related to their diet and a seasonal change in diet could affect ingested $\mathrm{Hg}$ concentrations. ${ }^{45}$ Little auks breeding in East Greenland are known to mainly forage on copepods during the breeding season. ${ }^{49}$ However, isotopic data suggested a change of diet soon after breeding, towards krill and fish larvae. ${ }^{50}$ 
Stomach content analyses performed on the same individuals as those used in the present study also showed a diet mainly composed of krill during late winter (March). ${ }^{22}$ Although we do not know if these different diets reflect different trophic positions, higher contamination observed during the non-breeding period could also partially result from a change in diet. Such a change could also be a second alternative explanation to trends interpreted by AMAP. Like Brünnich's guillemots (Uria lomvia) ${ }^{51}$ or northern fulmars (Fulmarus glacialis) ${ }^{52}$ which switch from a fish to a zooplankton-based diet during winter, other species could feed at lower trophic levels during the non-breeding period, resulting in lower $\mathrm{Hg}$ accumulations during the non-breeding period.

Moreover, our results suggested that female little auks that had higher head feather concentrations and so had accumulated more $\mathrm{Hg}$ during the non-breeding season laid smaller eggs. It is not possible from the present study to determine if $\mathrm{Hg}$ has a direct impact on little auk reproduction or if it rather reflects general contamination by trace metals or other contaminants. $\mathrm{Hg}$ concentrations measured in this study ranged from 0.4 to $5.7 \mu \mathrm{g}^{\mathrm{g}} \mathrm{g}^{-1} \mathrm{dw}(1.5$ to $5.7 \mu \mathrm{g} . \mathrm{g}^{-1} \mathrm{dw}$ in head feathers). These values are similar or below concentrations measured in similar tissues in other seabird species ${ }^{45,53,54}$ so a direct relationship between $\mathrm{Hg}$ concentration and female investment in the reproduction may seem surprising. $\mathrm{Hg}$ contamination thresholds that lead to adverse effect are poorly known in seabirds, especially for feather and blood matrices (see ${ }^{55,56}$ for other matrices). However, studies performed on other aquatic birds suggested that $\mathrm{Hg}$ concentrations from $5 \mu \mathrm{g} \cdot \mathrm{g}^{-1} \mathrm{dw}$ in feathers can cause reproductive impairment. ${ }^{57} \mathrm{~A}$ recent Arctic study suggested that low $\mathrm{Hg}$ concentrations in blood samples (approx. $3 \mu \mathrm{g} . \mathrm{g}^{-1} \mathrm{dw}$ ) could affect the reproductive success of kittiwakes by disrupting their endocrine system. ${ }^{16}$ Therefore, further studies are required to confirm the adverse effect found in our study and to understand the direct or indirect physiological link 
between $\mathrm{Hg}$ concentrations and egg synthesis in seabirds. Among others, it will be important to further consider selenium (Se) concentrations and the $\mathrm{Hg}$ :Se ratio. Indeed, Se interacts, through specific chemical mechanisms, with $\mathrm{Hg}$ to form nontoxic $\mathrm{Hg}$-Se complexes, and therefore acts as a protection against methyl-Hg toxicity. ${ }^{58}$ Hence, high Hg levels would not necessarily induce adverse toxicological effects if $\mathrm{Se}$ is abundant compared to $\mathrm{Hg}$ and if the $\mathrm{Hg}:$ Se ratio is low. Many seabird species are known to overwinter in huge numbers in the Northwest Atlantic, ${ }^{13,59-61}$ and like little auks, could be exposed to high $\mathrm{Hg}$ contamination risks with associated threats to their reproduction. Such studies would improve our understanding of the threat that $\mathrm{Hg}$ exposure represents for these vulnerable species, within and outside of the Arctic. 


\section{Acknowledgments}

We are grateful to J. Nezan, J. Chiffard Carricaburu, E. Buchel, L. de Sousa and R. Cavignaux for their hard work in the field, as well as to NANU Travel for their invaluable logistical support. We thank C. Churlaud and M. Brault-Favrou for assistance with laboratory work, and RA. Phillips for having provided tracking devices and advices on geolocation processing. Fieldwork was conducted under permits of the Ethics Committee of the French Polar Institute (MP/03/12/04/10 and MP/10/31/05/11) and with the permission of the Government of Greenland (permits $n^{\circ}$ 66.01.13 and 2011-047447). Fieldwork was co-funded by the French Polar Institute Paul Emile Victor (Grant 388 to D.G. and J.F.) and the European Commission (Marie Curie IEF to J.F.; Project 273061). Wintering little auks were collected off Newfoundland under Canadian Wildlife Service Scientific Take permit ST2753, and with the assistance of P. Ryan. The Contrat de Projet Etat Région (CPER 13) is also acknowledged for funding the AMA. J.F is supported by grants from the Région Poitou-Charentes and the European Commission (Marie Curie CIG; Project 631203).

Supporting Information Available. Figures S1, S2. Annual and sex differences in $\mathrm{Hg}$ concentrations measured in little auk blood and feather samples. This information is available free of charge via the Internet at http://pubs.acs.org. 


\section{References}

(1) AMAP Arctic Climate Issues 2011: Changes in Arctic Snow, Water, Ice and Permafrost. SWIPA 2011 Overview Report. Arctic Monitoring and Assessment Programme (AMAP), Oslo, Norway, 2012.

(2) UNEP Global Mercury Assessment 2013: Sources, Emissions, Releases and Environmental Transport. UNEP Chemicals Branch, Geneva, Switzerland, 2013.

(3) AMSA. Arctic Marine Shipping Assessment 2009 Report. Arctic Council, Troms $\emptyset$, Norway, 2009.

(4) AMAP Snow, water, ice and permafrost in the Arctic (SWIPA): climate change and the cryosphere. Arctic Monitoring and Assessment Programme (AMAP), Oslo, Norway, 2011.

(5) AMAP AMAP Assessment 2007: Oil and Gas Activities in the Arctic - Effects and Potential Effects. Volume 2; Arctic Monitoring and Assessment Programme (AMAP), Oslo, Norway, 2010.

(6) Rigét, F.; Braune, B.; Bignert, A.; Wilson, S.; Aars, J.; Born, E.; Dam, M.; Dietz, R.; Evans, M.; Evans, T.; Gamberg, M.; Gantner, N.; Green, N.; Gunnlaugsdóttir, H.; Kannan, K.; Letcher, R.; Muir, D.; Roach, P.; Sonne, C.; Stern, G.; Wiig, Ø. Temporal trends of Hg in Arctic biota, an update. Sci. Total Environ. 2011, 409, 3520-3526.

(7) De Laender, F.; Hammer, J.; Hendriks, A.; Soetaert, K.; Janssen, C. Combining monitoring data and modeling identifies PAHs as emerging contaminants in the Arctic. Environ. Sci. Technol. 2011, 45: 9024-9029

(8) AMAP AMAP Assessment 2011: Mercury in the Arctic; Arctic Monitoring and Assessment Programme (AMAP), Oslo, Norway, 2011. 
(9) Sonne, C. Health effects from long-range transported contaminants in Arctic top predators: An integrated review based on studies of polar bears and relevant model species. Environ. Intl. 2010, 36: 461-491.

(10) Dietz, R.; Sonne, C.; Basu, N.; Braune, B.; O'Hara, T.; Letcher, R. J.; Scheuhammer, T.; Andersen, M.; Andreasen, C.; Andriashek, D.; Asmund, G.; Aubail, A.; Baagøe, H.; Born, E. W.; Chan, H. M.; Derocher, A. E.; Grandjean, P.; Knott, K.; Kirkegaard, M.; Krey, A.; Lunn, N.; Messier, F.; Obbard, M.; Olsen, M. T.; Ostertag, S.; Peacock, E.; Renzoni, A.; Rigét, F. F.; Skaare, J. U.; Stern, G.; Stirling, I.; Taylor, M.; Wiig, Ø.; Wilson, S.; Aars, J. What are the toxicological effects of mercury in Arctic biota? Sci. Total Environ. 2013, $443,775-790$.

(11) Atwell, L.; Hobson, K. A.; Welch, H. E. Biomagnification and bioaccumulation of mercury in an arctic marine food web: insights from stable nitrogen isotope analysis. Can. J. Fish Aquat. Sci. 1998, 55, 1114-1121.

(12) Egevang, C.; Stenhouse, I. J.; Phillips, R. A.; Petersen, A.; Fox, J. W.; Silk, J. R. Tracking of Arctic terns Sterna paradisaea reveals longest animal migration. P. Natl. Acad. Sci. USA 2010, 107: 2078-2081

(13) Frederiksen, M.; Moe, B.; Daunt, F.; Phillips, R. A.; Barrett, R. T.; Bogdanova, M. I.; Boulinier, T.; Chardine, J. W.; Chastel, O.; Chivers, L. S.; Christensen-Dalsgaard, S.; Clément-Chastel, C.; Colhoun, K.; Freeman, R.; Gaston, A. J.; Gonzáles-Solís, J.; Goutte, A.; Grémillet, D.; Guilford, T.; Jensen, G. H.; Krasnov, Y.; Lorentsen, S-H.; Mallory, M. L.; Newell, M.; Olsen, B.; Shaw, D.; Steen, H.; Strøm, H.; Systad, G. H.; Thórarinsson, T. L.; Anker-Nilssen, T. Multicolony tracking reveals the winter distribution of a pelagic seabird on an ocean basin scale. Divers. Distrib. 2012, 18, 530-542.

(14) Gilg, O.; Moe, B.; Hanssen, S. A.; Schmidt, N. M.; Sittler, B.; Hansen, J.; Reneerkens, J.; Sabard, B.; Chastel, O.; Moreau, J.; Phillips, R. A.; Oudman, T.; Biersma, E. M.; Fenstad, 
A. A.; Lang, J.; Bollache, L. Trans-equatorial migration routes, staging sites and wintering areas of a High-Arctic avian predator: the long-tailed skua (Stercorarius longicaudus). PLoS ONE 2013, 8, e64614.

(15) Soerensen, A. L.; Sunderland, E. M.; Holmes, C. D.; Jacob, D. J.; Yantosca, R. M.; Skov, H.; Christensen, J. H.; Strode, S. A.; Mason, R. P. An improved global model for air-sea exchange of mercury: High concentrations over the North Atlantic. Environ. Sci. Technol. 2010, 44, 8574-8580.

(16) Tartu, S.; Goutte, A.; Bustamante, P.; Angelier, F.; Moe, B.; Clément-Chastel, C.; Bech, C.; Gabrielsen, G. W.; Bustnes, J. O.; Chastel, O. To breed or not to breed: endocrine response to mercury contamination by an Arctic seabird. Biol. Lett. 2013, 9, 20130317

(17) Goutte, A.; Bustamante, P.; Barbraud, C.; Delord, K.; Weimerskirch, H.; Chastel, O. Demographic responses to mercury exposure in two closely-related Antarctic top predators. Ecology 2014, 95, 1075-1086.

(18) Leat, E. H.; Bourgeon, S.; Magnusdottir, E.; Gabrielsen, G. W.; Grecian, W. J.; Hanssen, S. A.; Olafsdottir, K.; Petersen, A.; Phillips, R. A.; Strøm, H.; Ellis, S.; Fisk, A. T.; Bustnes, J. O.; Furness, R. W.; Borgå, K. Influence of wintering area on persistent organic pollutants in a breeding migratory seabird. Mar. Ecol. Prog. Ser. 2013, 491, 277-293.

(19) Gaston, A. J.; Jones, I. L. Bird families of the world: the auks; Oxford University Press: Oxford, U.K., 1998.

(20) Pyle, P. Identification guide to North American birds. Part II Anatidae to Alcidae; Slate Creek Press: Point Reyes Station, California, U.S.A., 2008.

(21) Mosbech, A.; Johansen, K. L.; Bech, N. I.; Lyngs, P.; Harding, A. M. A.; Egevang, C.; Phillips, R. A.; Fort, J. Inter-breeding movements of little auks Alle alle reveal a key postbreeding staging area in the Greenland Sea. Polar Biol. 2012, 35, 305-311. 
(22) Rosing-Asvid, A.; Hedeholm, R.; Arendt, K. E.; Fort, J.; Robertson, G. J. Winter diet of the little auk (Alle alle) in the Northwest Atlantic. Polar Biol. 2013, 36, 601-1608.

(23) Agusa, T.; Matsumoto, T.; Ikemoto, T.; Anan, Y.; Kubota, R.; Yasunaga, G.; Kunito, T.; Tanabe, S.; Ogi, H.; Shibata, Y. Body distribution of trace elements in black-tailed gulls from Rishiri Island, Japan: Age-dependent accumulation and transfer to feathers and eggs. Environ. Toxicol. Chem. 2005, 24, 2107-2120.

(24) Furness, R. W.; Muirhead, S. J.; Woodburn, M. Using bird feathers to measure mercury in the environment: relationships between mercury content and moult. Mar. Pollut. Bull. 1986, 17, 27-30.

(25) Thompson, D. R.; Bearhop, S.; Speakman, J. R.; Furness, R. W. Feathers as a means of monitoring mercury in seabirds: insights from stable isotope analysis. Environ. Pollut. 1998, 101, 193-200.

(26) Carravieri, A.; Bustamante, P.; Churlaud, C.; Fromant, A.; Cherel, Y. Moulting patterns drive within-individual variations of stable isotopes and mercury in seabird body feathers: implications for monitoring of the marine environment. Mar. Biol. 2014, 161, 963-968.

(27) Fort, J.; Beaugrand, G.; Grémillet, D.; Phillips, R. A. Biologging, Remotely-Sensed Oceanography and the Continuous Plankton Recorder Reveal the Environmental Determinants of a Seabird Wintering Hotspot. PLoS ONE 2012, 7, e41194.

(28) Fort, J.; Moe, B.; Strøm, H.; Grémillet, D.; Welcker, J.; Schultner, J.; Jerstad, K.; Johansen, K. L.; Phillips, R. A.; Mosbech, A. Multicolony tracking reveals potential threats to little auks wintering in the North Atlantic from marine pollution and shrinking sea ice cover. Divers. Distrib. 2013, 19, 1322-1332.

(29) Stempniewicz, L.; Skakuj, M.; Iliszko, L. The Little Auk Alle alle polaris of Franz Josef Land: a comparison with Svalbard Alle a. alle populations. Polar Res. 1996, 15, 1-10. 
(30) Blévin, P.; Carravieri, A.; Jaeger, A.; Chastel, O; Bustamante, P; Cherel, Y. Wide range of mercury contamination in chicks of Southern Ocean seabirds. PLOS ONE 2013, 8, e54508.

(31) Bearhop, S.; Teece, M. A.; Waldron, S.; Furness, R. W. Influence of lipid and uric acid on $\delta^{13} \mathrm{C}$ and $\delta^{15} \mathrm{~N}$ values of avian blood: implications for trophic studies. The Auk 2000, $117,504-507$.

(32) Kelly, J. F. Stable isotopes of carbon and nitrogen in the study of avian and mammalian trophic ecology. Can. J. Zool. 2000, 78, 1-27.

(33) Lisovski, S.; Hewson, C. M.; Klaassen, R. H.; Korner-Nievergelt, F.; Kristensen, M. W.; Hahn, S. Geolocation by light: accuracy and precision affected by environmental factors. Method. Ecol. Evol. 2012, 3, 603-612.

(34) Provencher, J. F.; Mallory, M. L.; Braune, B. M.; Forbes, M. R.; Gilchrist, H. G. Mercury and marine birds in Arctic Canada: effects, current trends and why we should be paying closer attention. Environ. Rev. 2014, 22, 244-255.

(35) Holmes, C. D.; Jacob, D. J.; Corbitt, E. S.; Mao, J.; Yang, X.; Talbot, R.; Slemr, F. Global atmospheric model for mercury including oxidation by bromine atoms. Atmos. Chem. Phys. 2010, 10, 12037-12057.

(36) Braune, B. M. Temporal trends of organochlorines and mercury in seabird eggs from the Canadian Arctic, 1975-2003. Environ. Pollut. 2007, 148, 599-613.

(37) Braune, B. M.; Mallory, M. L.; Gilchrist, H. G. Elevated mercury levels in a declining population of ivory gulls in the Canadian Arctic. Mar. Pollut. Bull. 2006, 52, 978-982.

(38) Baird, P. H. Black-legged kittiwake: Rissa tridactyla. In Birds of North America No. 92; Poole, A.; Gill, F., Eds.; Academy of Natural Sciences: Philadelphia, The American Ornithologists' Union: Washington D.C. 1994. 
(39) Donaldson, G. M.; Gaston, A. J.; Chardine, J. W.; Kampp, K.; Nettleship, D. N.; Elliot, R. D. Winter distribution of thick-billed murres from the eastern Canadian Arctic and western Greenland in relation to age and time of year, Occasional paper No. 96, Canadian Wildlife Service, Environment Canada: Ottawa, Canada, 1997.

(40) Hatch, S. A.; Nettleship, D. N. Northern Fulmar (Fulmarus glacialis). In The Birds of North America No. 361; Poole, A.; Gill, F., Eds.; Academy of Natural Sciences: Philadelphia, The American Ornithologists' Union: Washington D.C. 1998.

(41) Mallory, M. L. At the gate to Hell: studying fulmars in northern Nunavut. BirdWatch Canada 2005, 32, 8-11.

(42) Mallory, M. L.; Braune, B. M. Tracking contaminants in seabirds of Arctic Canada: Temporal and spatial insights. Mar. Pollut. Bull. 2012, 64, 1475-1484.

(43) Hobson, K. A.; Welch, H. E. Determination of trophic relationships within a high arctic marine food web using $\delta^{13} \mathrm{C}$ and $\delta^{15} \mathrm{~N}$ analysis. Mar. Ecol. Prog. Ser. 1992, 84, 9-18.

(44) Hobson, K. A.; Piatt, J. F.; Pitocchelli, J. Using stable isotopes to determine seabird trophic relationships. J. Anim. Ecol. 1994, 63:786-798.

(45) Carravieri, A.; Bustamante, P.; Churlaud, C.; Cherel, Y. Penguins as bioindicators of mercury contamination in the Southern Ocean: Birds from the Kerguelen Islands as a case study. Sci. Total Environ. 2013, 454, 141-148.

(46) McFarlane Tranquilla, L. A.; Montevecchi, W. A.; Hedd, A.; Fifield, D. A.; Burke, C. M.; Smith, P. A.; Regular, P. M.; Robertson, G. J.; Gaston, A. J.; Phillips R. A. Multiplecolony winter habitat use by Murres (Uria spp.) in the Northwest Atlantic Ocean: Implications for marine risk assessment. Mar. Ecol. Prog. Ser. 2013, 472: 287-303.

(47) Linnebjerg, J. F.; Fort J.; Guilford, T.; Reuleaux, A.; Mosbech, A.; Frederiksen, M. Sympatric breeding auks shift between dietary and spatial resource partitioning across the annual cycle. PLOS ONE 2013, 8, e72987. 
(48) Stenhouse, I. J.; Egevang, C.; Phillips, R. A. Trans-equatorial migration, staging sites and wintering area of Sabine's Gulls Larus sabini in the Atlantic Ocean. Ibis 2012, 154, 42-51.

(49) Harding, A. M. A.; Hobson, K. A.; Walkusz, W.; Dmoch, K.; Karnovsky, N. J.; Van Pelt, T. I.; Lifjeld, J. T. Can stable isotope (d13C and d15N) measurements of little auk (Alle alle) adults and chicks be used to track changes in high-Arctic marine foodwebs? Polar Biol. 2008, 31, 725-733.

(50) Fort, J.; Cherel, Y.; Harding, A. M. A.; Welker, J.; Jakubas, D.; Steen, H.; Karnovsky, N. J.; Grémillet, D. Geographical and seasonal changes in isotopic niche of little auks. Mar. Ecol. Prog. Ser. 2010, 414, 293-302.

(51) Elliot, R. D.; Ryan, P. C.; Lidster, W. W. The winter diet of thick-billed murres in coastal Newfoundland waters. Stud. Avian Biol. 1990, 14, 125-138.

(52) Mallory, M. L.; Karnovsky, N. J.; Gaston, A. J.; Hobson, K. A.; Provencher, J. F.; Forbes, M. R.; Hunt, G. L.; Byers, T.; Dick, T. A. Temporal and spatial patterns in the diet of northern fulmars (Fulmarus glacialis) in the Canadian High Arctic. Aquat. Biol. 2010, $10,181-191$.

(53) Kim, E. Y.; Murakami, T.; Saeki, K.; Tatsukawa, R. Mercury levels and its chemical form in tissues and organs of seabirds. Arch. Environ. Contam. Toxicol. 1996, 30, 259-266.

(54) Vo, A. T. E.; Bank, M. S.; Shine, J. P.; Edwards, S. V. Temporal increase in organic mercury in an endangered pelagic seabird assessed by century-old museum specimens. $P$. Natl. Acad. Sci. USA 2011, 108, 7466-7471.

(55) Shore, R.; et al. Mercury in non-marine birds and mammals. In Environmental contaminants in biota; Beyer, W., Meador, J., Eds.; CRC Press: New York 2011; pp. 609626. 
(56) Provencher, J. F.; Braune, B. M.; Gilchrist, H. G.; Forbes, M. R.; Mallory, M. L. Trace element concentrations and gastrointestinal parasites of Arctic terns breeding in the Canadian High Arctic. Sci. Total Environ. 2014, 476, 308-316.

(57) Burger, J.; Gochfeld, M. Risk, mercury levels, and birds: relating adverse laboratory effects to field biomonitoring. Environ. Res. 1997, 75, 160-172.

(58) Cuvin-Aralar, M. L. A.; Furness, R. W. Mercury and selenium interaction: a review. Ecotox. Environ. Safe. 1991, 21, 348-364.

(59) Fifield, D. A.; Lewis, K. P.; Gjerdrum, C.; Robertson, G. J.; Wells, R. Offshore Seabird Monitoring Program. Environment Studies Research Funds Report No. 183, St. John's, Canada, 2009.

(60) Gaston, A. J.; Smith, P. A.; McFarlane Tranquilla, L. A.; Montevecchi, W. A.; Fifield, D. A.; Gilchrist, G.; Hedd, A.; Mallory, M. L.; Robertson, G. J.; Phillips, R. A. Movements and wintering areas of breeding age Thick-billed Murres Uria lomvia from two colonies in Nunavut, Canada, as determined by solar geolocation. Mar. Biol. 2011, 158, 1929-1941.

(61) Hedd, A.; Montevecchi, W. A.; McFarlane Tranquilla, L.; Burke, C. M.; Fifield, D. A.; Robertson, G. J.; Phillips, R. A.; Gjerdrum, C.; Regular, P. M. Reducing uncertainty on the Grand Bank: tracking and vessel surveys indicate mortality risks for common murres in the Northwest Atlantic. Anim. Conserv. 2011, 14, 1-12. 


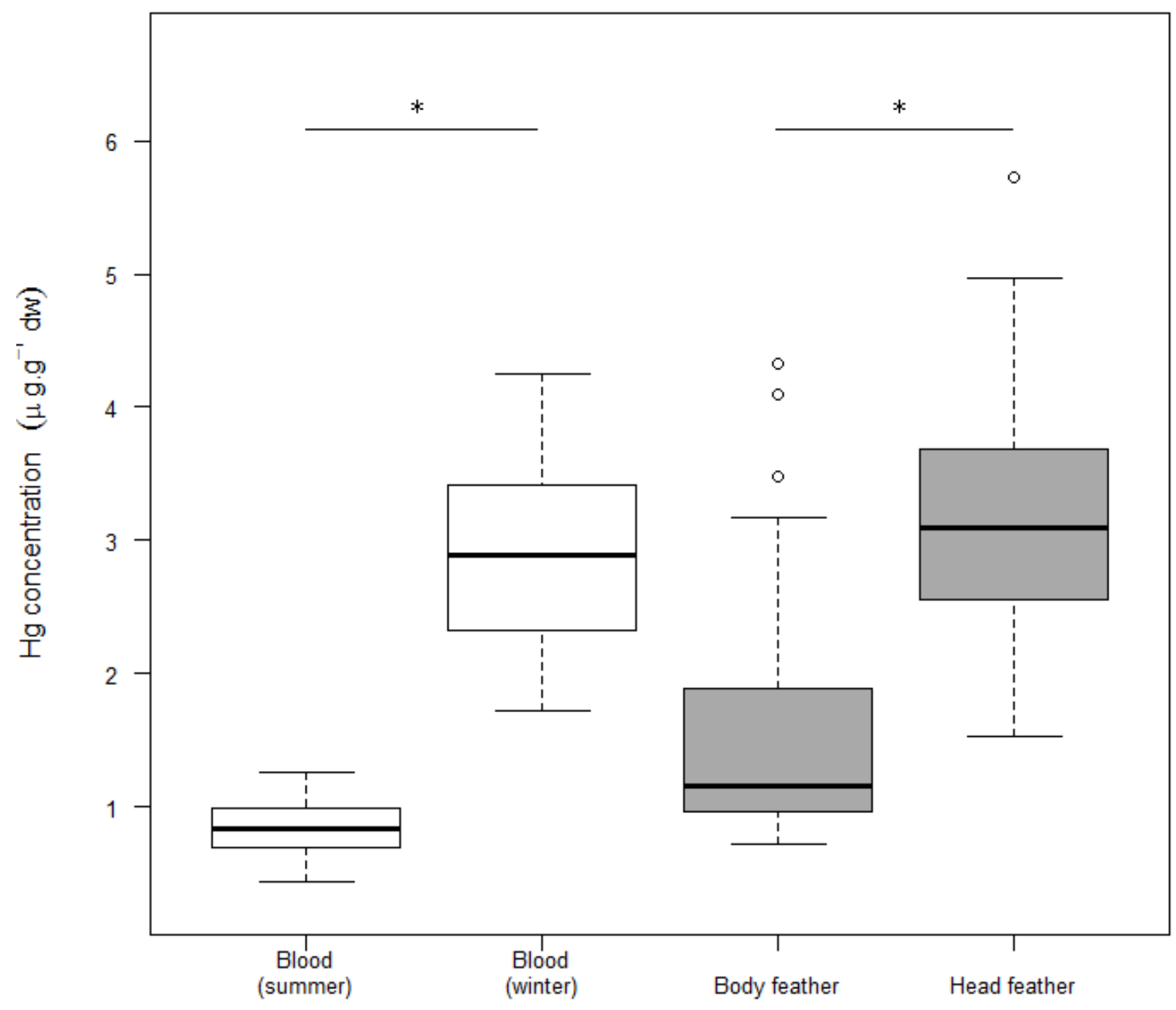

Figure 1. $\mathrm{Hg}$ concentrations (in $\mu \mathrm{g} \cdot \mathrm{g}^{-1}$ dry weight) measured in little auk blood and feather samples. Body feather concentrations indicate summer contamination; while head feather concentrations indicate winter contamination (see Introduction and Materials and Methods for details). Stars indicate significant differences between seasons in both blood and feathers $(\mathrm{p}<$ $0.001)$ 


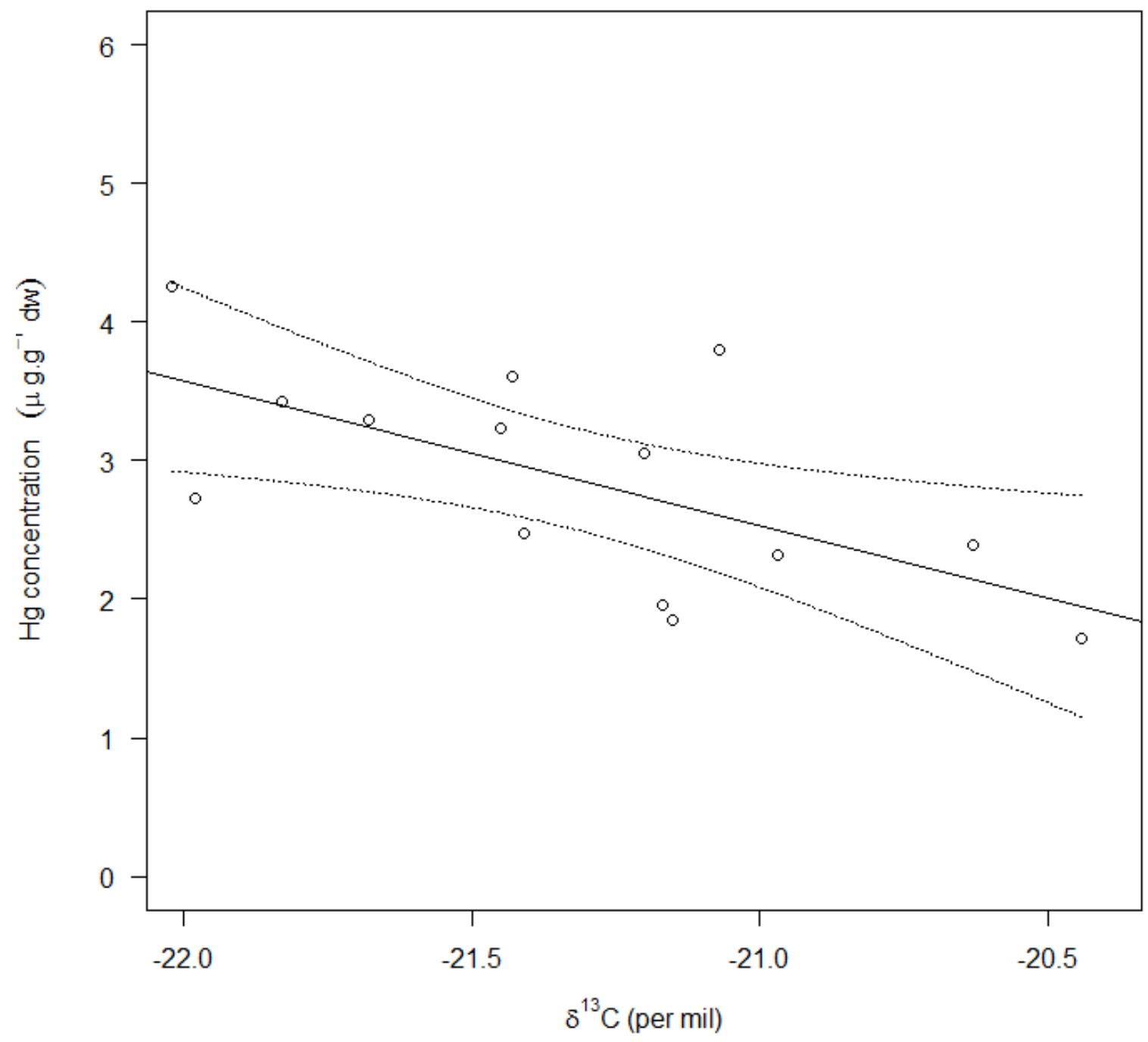

Figure 2. Blood $\mathrm{Hg}$ concentrations (in $\mu \mathrm{g} \cdot \mathrm{g}^{-1}$ dry weight) in relation to the $\delta^{13} \mathrm{C}$ isotopic values of little auks wintering in the northwest Atlantic. Higher (less negative) $\delta^{13} \mathrm{C}$ values indicate a more inshore diet, and lower (more negative) a more offshore diet (Hobson \& Welch 1992, Hobson et al. 1994). 


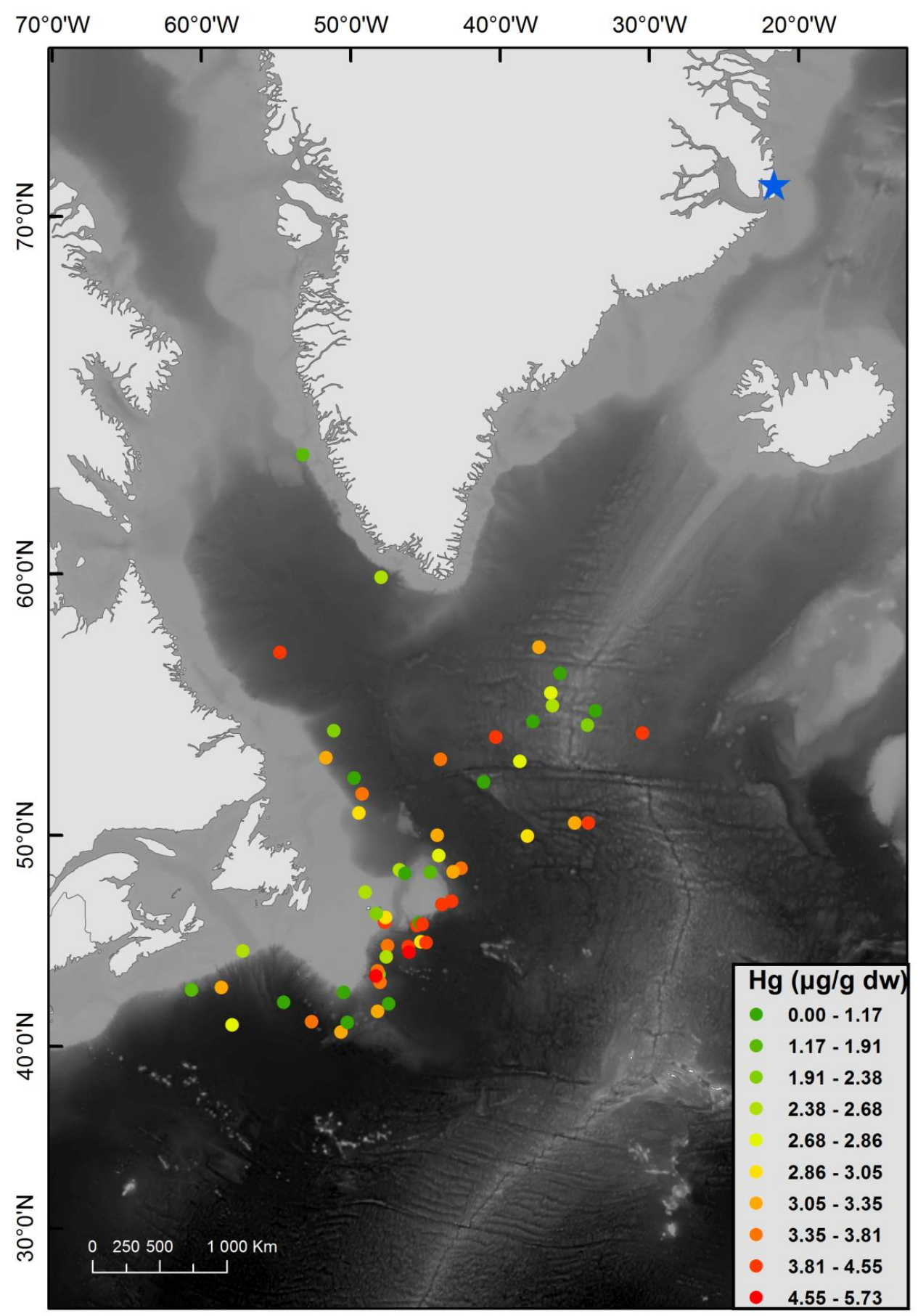

Figure 3. $\mathrm{Hg}$ concentrations (in $\mu \mathrm{g} \cdot \mathrm{g}^{-1}$ dry weight) measured in head feathers of little auks breeding in East Greenland, in relation to their non-breeding distribution in the Northwest Atlantic. Each point represents the median distribution of individually-tracked little auks during the non-breeding period (15 October- 20 February). The blue star represents the breeding colony where birds were equipped. 


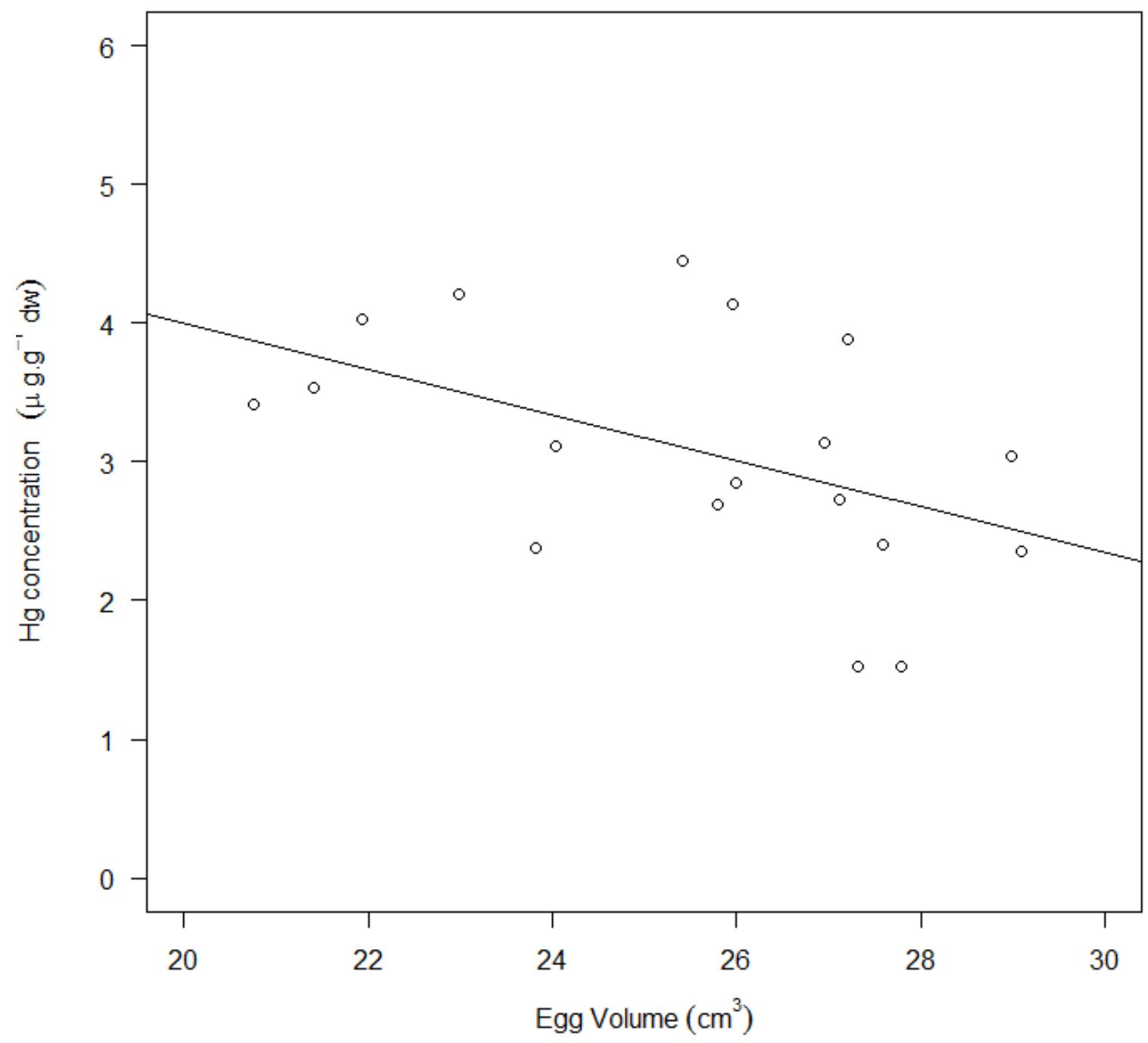

Figure 4. Egg volume $\left(\mathrm{cm}^{3}\right)$ of female little auks breeding in East Greenland in relation the $\mathrm{Hg}$ concentrations (in $\mu \mathrm{g} \cdot \mathrm{g}^{-1}$ dry weight) measured in their head feather (i.e. accumulated during the non-breeding period; see Introduction for details). 